\title{
SOLUTIONS INVESTIGATION OF THE ENERGY, ELECTRICITY AND WATER CRISIS IN SOUTHEASTERN BRAZIL DURING 2014 \\ Akhmetov R.R. ${ }^{1}$, Krainov S.A. ${ }^{2}$ Email: Akhmetov17116@scientifictext.ru
}

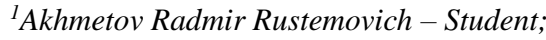 \\ ${ }^{2}$ Krainov Sergei Alexeevich - Student, \\ PETROLEUM ENGINEERIND DEPARTMENT, \\ SAINT PETERSBURG MINING UNIVERSITY, \\ SAINT PETERSBURG
}

\begin{abstract}
: in consequence of the reduction in the capacities of the main power plants, paper's aim was to take emergency measures to provide the country with energy. Develop a strategy for redistributing energy production in case of repeated drought. Propose measures to prevent future drought in Brazil. As emergency measures it was proposed to import petroleum. It could easily compensate capacity of 4 chief hydroelectric power stations in a week $\left(1.9\right.$ million $\left.\mathrm{m}^{3}\right)$ and would take 1.5 billion \$ to purchase. Then solar energy plants in 12 months would have an average annual output of about $286 \mathrm{TW} / \mathrm{h}$, which is almost 3 times more than the average annual output of Itaipu HES. According to Brazil coastal zone landscape and coastal belt density of population each power plant would work for around 100 years and give $250 \mathrm{~W} / \mathrm{h}$. Wind energy is less productive, but by 2 times cheaper than solar energy. Ameliaration, soil preparation and forest restoration were proposed as ecology remedies.

Keywords: drought, energy, electricity, Brazil.

\section{ИССЛЕДОВАНИЕ РЕШЕНИЙ ЭНЕРГЕТИЧЕСКОГО, ЭЛЕКТРИЧЕСКОГО И ВОДНОГО КРИЗИСА В ЮГО-ВОСТОЧНОЙ БРАЗИЛИИ В 2014 ГОДУ Ахметов P.P. ${ }^{1}$, Крайнов С.А. ${ }^{2}$}

\author{
${ }^{1}$ Ахметов Радмир Рустемович - студент; \\ ${ }^{2}$ Крайнов Сергей Алексеевич - студент, \\ Санкт-Петербургский горный университет, \\ г. Санкт-Петербург
} кафедра транспорта и хранения нефти и газа,
\end{abstract}

\begin{abstract}
Аннотация: в статье предпринимается попытка разработать стратегию распределения энергии 8 случае повторной засухи и предложить меры предотвращения засухи в Бразилии. В качестве срочных мер было предложено импортировать нефть, что компенсирует производительность 4 главных гидроэлектростанций страны за неделю и затраты составят 1.9 миллиарда долларов. Строчтельство солнечных электростанций за 12 месяцев обеспечит мощзность 286 TВ/ч, что в 3 раза превышает мощность главной ГЭС страны. Приливные электростанции позволят вырабатывать 250 B/ч на протяжении 100 лет. Ветряные электростанциии менее мощны, но в 2 раза дешевле солнечных. $A$ мелиорация и восстановление лесов были предложены в качестве экологических мер.
\end{abstract}

Ключевые слова: засуха, энергия, электричество, Бразилия.

The southeast region of Brazil has been experiencing since summer 2014 a major drought event leading to a number of impacts in water availability for human consumption, agricultural irrigation and hydropower production. As is known, 75\% of the electricity generated in Brazil falls on hydroelectric power stations that are located in the channels of the largest rivers, such as Parana, San Francisco and Amazon. Most rivers either dried out or significantly reduced their capacity. In addition to disruptions at the hydropower station, the second largest source of electricity in the country - ethanol, which is made on the basis of sugar cane - suffered. A high percentage of crops due to lack of irrigation [1,2,3]. A quarter of the country's inhabitants had limit access to water. The north-eastern regions suffered so much because of aridity, that the government decided to change the channel of one of the largest rivers of Brazil - San Francisco. Also, several artificial river hoses were assigned to a territory with water shortage. The drought was largely due to the anthropogenic factor. First, in the last few decades, in Brazil, there is a massive urbanization, which entails irrational use of water resources. The felling of trees has significantly increased. Most of the forest goes to building materials and spaces for the new construction of sprawling cities $[4,5]$. It was also a real hard time for animals (Figure 1). 


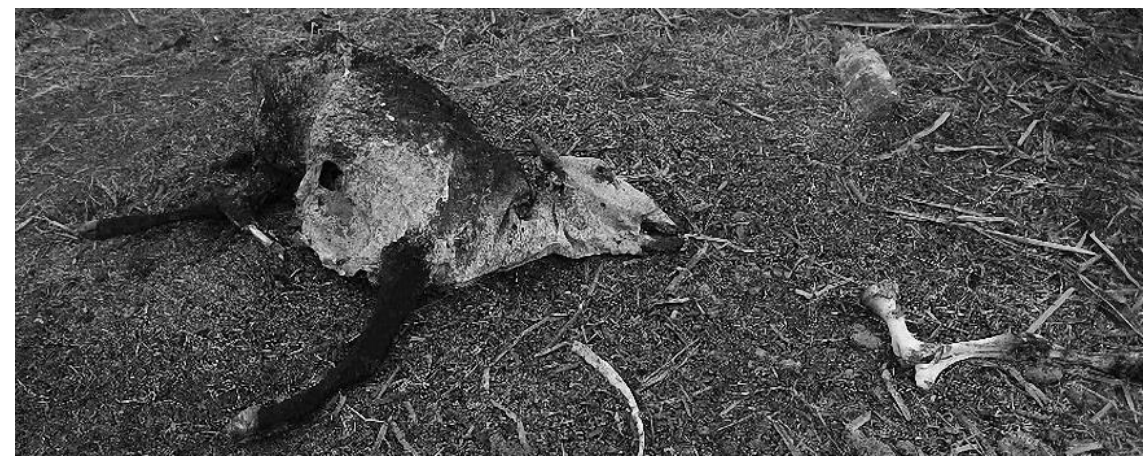

Fig. 1. Dead cow from behind the drought in 2014. Source: (RICARDO MORAES/REUTERS)

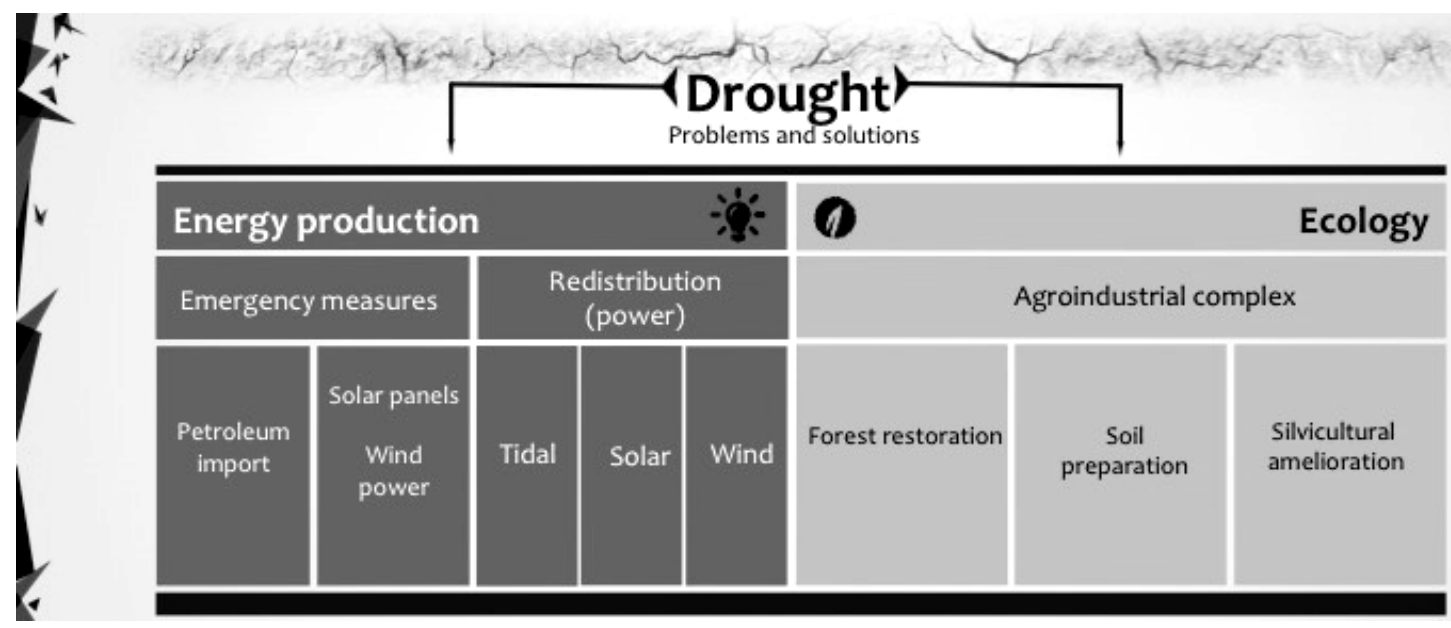

Fig. 2. Paper's executive summary

First emergency measure would be to import petroleum from countries in neighborhood. The speed of this measure is its principal advantage. It would take only 1 week to accomplish this remedy. It could also easily compensate capacity of 4 chief hydroelectric power stations of this country (Tikurui, Santu Antonio, IliyaSolteira, Shingo) by dint of around 1600 fossil fuel burning power stations located in Brazil (Figure 3). The main disadvantage of the measure is its cost. It would take 1.5 billion $\$$ to purchase essential oil amount.
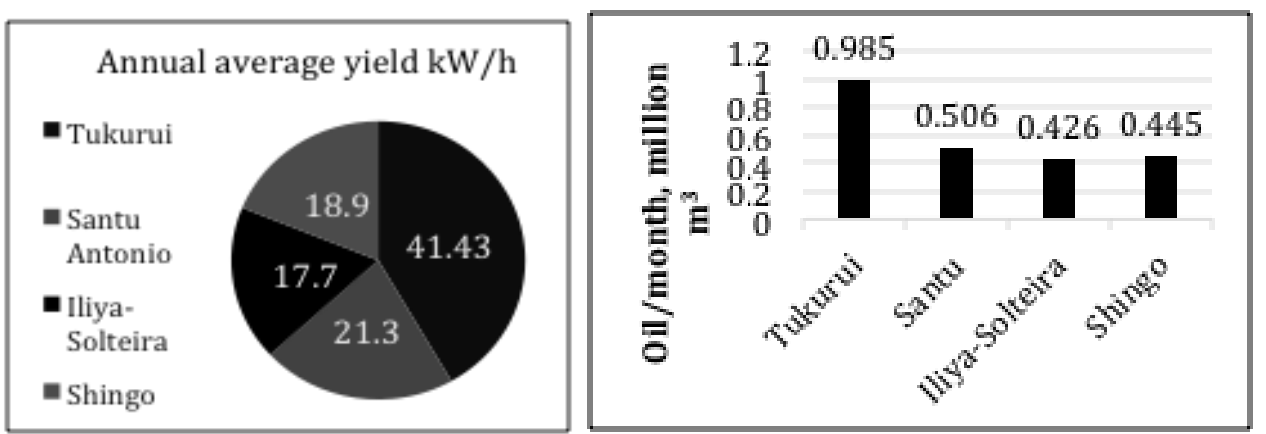

Fig. 3. Average yield of 4 main HES, Oil needed to compensate HES energy

Another 2 remedies are using solar panels, wind generators by households. It will reduce demand for the delivery of the central electric network an upsurge the quantity of energy for industrial consumption. Time essential to implement measures is 6 and 12 months respectively.

The first measure for the redistribution of energy capacity: construction of tidal power plants. Advantages are accuracy, impact on landscape, durability (100 years), average power, Brazil coastal belt density of population: 100 people $/ \mathrm{km}^{2}$. Other remedies are the appliance of wind and solar energy. The advantage of soar energy is that there are 300 days of sunshine a year in the northeast of Brazil. Taking into account the average intensity of solar radiation, a solar power plant equal in area to the Itaipu hydroelectric power station would have an average annual output of about $286 \mathrm{TW} / \mathrm{h}$, which is almost 3 times more than the average annual output of Itaipu. The benefit of wind energy is that it is rather cheap. The ratio of wind and solar energy costs are presented on figure 4. 


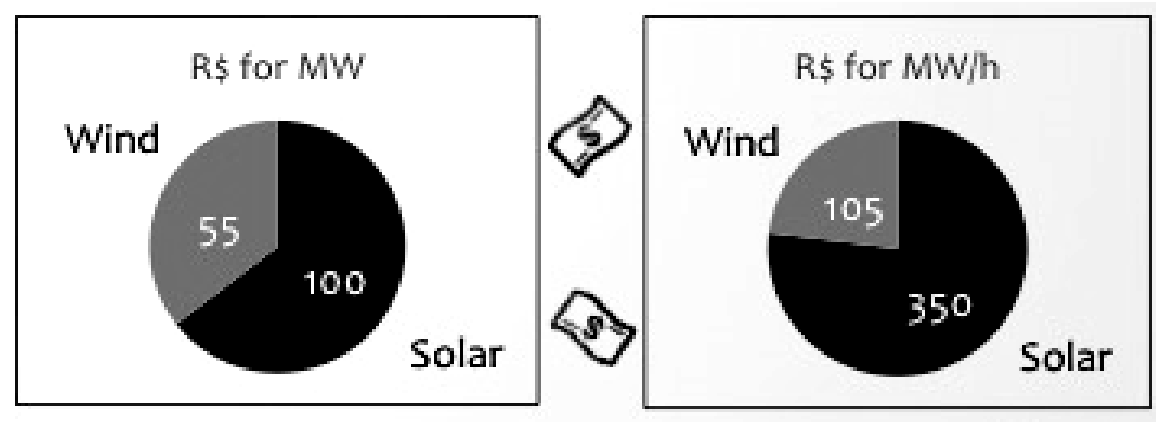

Fig. 4. The ratio of wind and solar energy costs

First of all, it is essential to end the destruction of tropical forests and start their partial restoration. Here are merits and of this remedy: deforestation helps to reduce the amount of precipitation, transpiration process stops, stable transport of moisture from the ocean to the centers of the continents. This remedy is important cause forest clearance was much higher in 2014 (244 square $\mathrm{km}$ ) than in 2013 (43 square $\mathrm{km}$ ). It is also important to implement system of zero soil preparation. Such a system of farming preserves water much better, especially in drought conditions, prevents water and wind erosion of the soil. This avoids the destruction of the forest in order to obtain new areas suitable for farming, and saves resources - fuel, fertilizer, labor, time, lower depreciation costs. Finally, silvicultural amelioration permits to reduce wind speed - decreases volatility by $10-30 \%$, and the relative humidity of air increases by 5-10\%. Another huge advantage is cheapness and absolute ecological harmlessness [6].

\section{References / Список литературы}

1. Coelho C.S., Cardoso D.F. and Firpo M.F., 2015. Precipitation Diagnostics of an Exceptionally Dry Event in Sao Paulo. Brazil. Theoretical and Applied Climatology. 1-16.

2. Seth A.K., Fernandes K. and Camargo S., 2015. Two Summers of Sao Paulo Drought: Origins in the Western Tropical Pacific. Geophysical Research Letters, in Press.

3. Silva W.L., Nascimento, M.A. and Menezes W.F., 2015. Atmospheric Blocking in the South Atlantic during the Summer, 2014: A Synoptic Analysis of the Phenomenon. Atmospheric and Climate Sciences. 5. 386-393.

4. Hartmann D.L., 2015. Pacific Sea Surface Temperature and the Winter of 2014. Geophysical Research Letters. 42. 1894-1902.

5. Munich Re., 2015. Natural Catastrophes 2014. Analyses, Assessments, Positions. TOPICS-GEO, 2014. Munich. 67 p.

6. Brasil GDP Annual growth rate. Instituto brasileiro de geografia e estatistica. 